\title{
Penerapan Standar Akuntansi Nasional Pada Organisasi Nirlaba Bidang Sosial Kemanusiaan di Bali
}

\author{
MADE ARISTIA PRAYUDI ${ }^{*} \&$ MADE NARSA ${ }^{21}$ \\ ${ }^{1}$ Program Studi Akuntansi, Universitas Pendidikan Ganesha, Jalan Udayana No.11 Singaraja, Indonesia. \\ ${ }^{2}$ Program Studi Akuntansi, Universitas Airlangga, Kampus B Jl. Airlangga No.4, Surabaya, 60286, Telp. +62 315033642 Indonesia \\ ${ }^{*}$ Corresponding author, E_mail address: prayudimadearistia.acc@gmail.com
}

\begin{abstract}
The purpose of this study are to evaluate organization compliance level with Indonesian GAAP No. 45: 'Financial Statement of Not-for-Profit Organization', investigate preparers' and users' perceptions toward the standard; and determine whether or not there is a significant difference between the perceptions of the two groups. Data were collected through questionnaires were distributed to 30 financial staffs of 10 units of Indonesian Red Cross Society (as the preparer group) and to 30 local government officers (as the user group) of Health Department, Social Service Department, and Public Welfare Bureau in Bali Province of Indonesia. The data was analyzed descriptively and using the Independent t-Test and Mann-Whitney test. The results show that only one-third of the organizations are categorized as compliant, users have higher perceptions of the importance and usefulness of the standard and there are significant differences between the groups in their perception toward the standard.

Keywords: Indonesian GAAP No. 4;Not-For-Profit Organization; Indonesian Red Cross Society; Compliance; Perception.
\end{abstract}

\begin{abstract}
ABSTRAK
Tujuan dari penelitian ini adalah untuk mengevaluasi tingkat kepatuhan organisasi dengan PABU Indonesia Nomor 45: 'Laporan Keuangan Tidakuntuk-Laba Organisasi', menyelidiki persepsi preparers 'dan pengguna' terhadap standar dan menentukan apakah atau tidak ada perbedaan yang signifikan antara persepsi dari dua kelompok. Data dikumpulkan melalui kuesioner yan didistribusikan ke 30 staf keuangan dari 10 unit Palang Merah Indonesia (sebagai kelompok preparer) dan 30 petugas pemerintah daerah (sebagai kelompok pengguna) dari Departemen Kesehatan, Departemen Sosial, dan Kesejahteraan Masyarakat Biro di Provinsi Bali Indonesia. Data dianalisis secara deskriptif dan menggunakan Independent t-Test dan Mann-Whitney tes. Hasil penelitian menunjukkan bahwa (a) hanya sepertiga dari organisasi dikategorikan sebagai compliant; (b) pengguna memiliki persepsi yang lebih tinggi tentang pentingnya dan kegunaan standar; dan (c) ada perbedaan yang signifikan antara kelompok dalam persepsi mereka terhadap standar.

Kata Kunci:PABU No. 45; Organisasi Nirlaba; Institusi Palang Merah Indonesia;Kepatuhan; Persepsi.
\end{abstract}

\section{PENDAHULUAN}

Banyak peneliti pada bidang Akuntansi sependapat bahwa standar akuntansi merupakan salah satu faktor penting, di antara faktor-faktor lainnya, yang dapat menentukan kualitas pelaporan keuangan suatu organisasi (mis: Levitt, 1998; Hope, 2003; Barth, Landsman, dan Lang, 2008;

Holthausen, 2009; Hossain dan Nurunnabi, 2011). Ketika diterapkan secara memadai, standar akuntansi diyakini akan menghasilkan angka-angka akuntansi yang merefleksikan secara lebih baik kondisi keuangan organisasi sehingga mampu menyediakan informasi yang juga akan lebih relevan bagi pihak-pihak berkepentingan dalam pengambilan keputusan. Meskipun demikan, terdapat bukti empiris bahwa beberapa organisasi pada negara-negara di wilayah Asia justru menunjukkan sikap ketidakpatuhan dalam hal penerapan standar akuntansi yang berlaku secara nasional, misalnya sebagaimana diamati oleh Rahman (2000) pada organisasi bisnis di Korea, 
Thailand, Indonesia, Malaysia dan Filipina; oleh Dang-Duc (2011) pada Usaha Mikro, Kecil dan Menengah (small and medium-sized enterprises-SMEs) di Vietnam; dan oleh World Bank (2007) pada Badan Usaha Milik Negara (state-owned enterprisesSOEs) di Pakistan. Temuan ini mengindi-kasikan bahwa isu terkait perilaku kepatuhan organisasi terhadap standar akuntansi dalam penyusunan laporan keuangan masih layak untuk diperdebatkan, khususnya pada organisasi dalam lingkup regional Asia.

Salah satu tujuan penelitian ini adalah untuk mengevaluasi tingkat kepatuhan penerapan standar akuntansi dalam penyusunan laporan keuangan pada organisasi nirlaba bidang sosial kemanusiaan, yaitu Palang Merah Indonesia (selanjutnya dinyatakan dengan PMI). PMI merupakan suatu organisasi nasional yang berdiri atas azas perikemanusiaan dan atas dasar sukarela dengan tidak membeda-bedakan bangsa, golongan dan paham politik (Keppres RI No. 246 tahun 1963). Dalam pelaksanaan fungsinya, PMI memperoleh dukungan donasi yang begitu besar dari berbagai pihak dengan latar belakang yang berbeda, baik donor perorangan maupun institusi, mulai dari pemerintah hingga organisasi bisnis (Palang Merah Indonesia, 2011).

Sebagai sebuah organisasi nirlaba yang berkedudukan di Indonesia, PMI diwajibkan untuk melaksanakan pelaporan keuangan berdasarkan Pernyataan Standar Akuntansi Keuangan Nomor 45 (PSAK 45) tentang Pelaporan Keuangan

Organisasi Nirlaba (Palang Merah Indonesia, 2010). PSAK 45 diterbitkan dan disahkan oleh Ikatan Akuntan Indonesia (IAI) pada 23 Desember 1997 serta telah berlaku efektif sejak 1 Januari 2000. Standar akuntansi ini selanjutnya menjadi acuan baku bagi penyusunan laporan keuangan organisasi nirlaba di Indonesia yang memenuhi karakteristik sebagaimana telah disyaratkan dalam standar tersebut (Ikatan Akuntan Indonesia, 2010)

Penelitian terkait kepatuhan penerapan standar pelaporan keuangan pada organisasi nirlaba menjadi sesuatu yang urgen dengan mempertimbangkan karakteristik lingkungan pertanggungjawaban keuangan pada jenis organisasi ini. Secara umum, perhatian terhadap aspek akuntabilitas pada organisasi nirlaba memang lebih lemah jika dibandingkan dengan organisasi laba (Kreander et al., 2009). Stakeholder organisasi nirlaba memiliki insentif pengawasan yang lebih rendah jika dibandingkan para stakeholder (investor) organisasi laba yang secara langsung berkepentingan secara ekonomis terhadap pengelolaan modal yang telah diinvestasikan. Kondisi seperti ini tak pelak dapat memunculkan sikap-sikap keacuhan organisasi atas kewajiban pengelolaan yang transparan dan akuntabel.

Di sisi lain, hasil penelitian Rahman (2000) juga menemukan adanya perilaku menyimpang berupa resistensi terhadap transparansi (resistance to transparency) yang melekat dalam tradisi pengelolaan keuangan organisasi di beberapa negara di Asia. Konsekuensinya, para penyusun laporan keuangan di negara-negara tersebut seringkali justru menghindari penerapan standar-standar akuntansi yang sejatinya dapat membuat laporan keuangan organisasi menjadi lebih transparan (Rahman, 2000). Mempertimbangkan fenomena tersebut, penelitian ini juga bertujuan untuk menginvestigasi persepsi para penyusun laporan keuangan terhadap penerapan standar keuangan yang berlaku relevan bagi organisasi.

Di samping itu, investigasi dilakukan pula terhadap persepsi pengguna laporan keuangan karena pada hakikatnya laporan keuangan merupakan media komunikasi dan representasi pemenuhan kepentingan antara pihak penyusun dan pengguna laporan keuangan. Terakhir, penelitian ini sekaligus bertujuan untuk 
menentukan kemungkinan adanya perbedaan persepsi di antara kedua belah pihak yang dimaksud. Bagian selanjutnya dalam tulisan ini menjabarkan beberapa literatur dan argumen teoretis yang mendasari dirumuskannya hipotesis penelitian, diikuti pembahasan atas metode pengumpulan dan analisis data berikut hasil-hasil yang menjadi temuan. Tulisan ini kemudian ditutup dengan penyampaian kesimpulan, implikasi, saran serta keterbatasan penelitian.

\section{TINJAUAN LITERATUR DAN PERUMUSAN HIPOTESIS}

\section{PENYATAAN STANDAR AKUNTANSI KEUANGAN NOMOR 45 (PSAK 45)}

Pernyataan Standar Akuntansi Keuangan Nomor 45 (PSAK 45) secara khusus membahas tentang pelaporan keuangan pada organisasi nirlaba. Pernyataan ini berlaku bagi laporan keuangan yang disajikan oleh organisasi nirlaba yang memenuhi karakteristik berupa perolehan sumber daya entitas yang berasal dari para penyumbang yang tidak mengharapkan pembayaran kembali atau manfaat ekonomi yang sebanding dengan jumlah sumber daya yang diberikan. Ketentuan lain, organisasi merupakan entitas yang menghasilkan barang dan/atau jasa tanpa bertujuan memupuk laba, dan kalau suatu entitas menghasilkan laba, maka jumlahnya tidak pernah dibagikan kepada para pendiri atau pemilik entitas tersebut. Status kepemilikannya tidak seperti lazimnya pada organisasi bisnis, dalam arti bahwa kepemilikan dalam organisasi nirlaba tidak dapat dijual, dialihkan, atau ditebus kembali, atau kepemilikan tersebut tidak mencerminkan proporsi pembagian sumber daya entitas pada saat likuidasi atau pembubaran entitas.

Bentuk laporan keuangan untuk organisasi nirlaba sebagaimana diatur dalam PSAK 45 terdiri dari (a) laporan posisi keuangan yang menyediakan informasi mengenai aktiva, kewajiban, dan aktiva bersih dan informasi mengenai hubungan di antara unsur-unsur tersebut pada waktu tertentu; (b) laporan aktivitas yang menyediakan informasi mengenai (i) pengaruh transaksi dan peristiwa lain yang mengubah jumlah dan sifat aktiva bersih, (ii) hubungan antar transaksi, dan peristiwa lain, dan (iii) bagaimana penggunaan sumber daya dalam pelaksanaan berbagai program atau jasa; (3) laporan arus kas yang menyajikan informasi mengenai penerimaan dan pengeluaran kas dalam suatu periode, dan catatan atas laporan keuangan.

Penerapan PSAK untuk pelaporan keuangan suatu entitas selanjutnya merupakan suatu bentuk kewajiban bagi organisasi. Hal ini dapat ditelusuri dari beberapa ketetapan yang dikeluarkan pemerintah, misalnya sebagaimana Undang-undang Nomor 8 Tahun 1995 tentang Pasar Modal pasal 69 ayat 1 menyebutkan:

"Laporan keuangan yang disampai-kan kepada

Bapepam wajib disusun berdasarkan prinsip akuntansi yang berlaku umum”.

Demikian pula, dalam Keputusan Ketua Badan Pengawas Pasar Modal Tentang Perubahan Peraturan Nomor VIII.G.7 Tentang Pedoman Penyajian Laporan Keuangan bagian 1 (b) menyatakan:

“... bentuk, isi dan persyaratan dalam penyajian laporan keuangan yang tidak diatur dalam peraturan ini, harus mengikuti Pernyataan Standar Akuntansi Keuangan (PSAK) yang diterbitkan oleh Ikatan Akuntan Indonesia (IAI)"

\section{TEORI STAKEHOLDER DAN PERSEPSI PENYUSUN DAN PENGGUNA LAPORAN KEUANGAN}

Teori stakeholder mengajukan suatu konsep keorganisasian berupa argumentasi bahwa seluruh pihak yang bekepentingan memiliki hak untuk memperoleh informasi mengenai aktivitas 
organisasi (Ousama et al., 2011). Informasi tersebut harus dapat merefleksikan pemenuhan kewajiban manajemen organisasi terkait penyediaan informasi kepada para stakeholder. Meskipun demikian, dengan mempertimbangkan bahwa stakeholder bersifat sangat luas dan variatif, harapan dan kebutuhan atas informasi bagi pihak-pihak tersebut tentunya dapat sangat beragam. Konsekuensinya, prosedur-prosedur dan teknik-teknik pelaporan keuangan yang diharapkan dapat diterapkan oleh manajemen organisasi dalam rangka penyediaan informasi tersebut pun dapat dipersepsikan berbeda antar stakeholder yang ada.

Perihal persepsi pihak penyusun dan pengguna laporan keuangan sebelumnya telah banyak diinvestigasi, misalnya terhadap atribut-atribut kualitas audit di Amerika (Carcello et al., 1992); terhadap perubahan metode akuntansi pada universitas di Australia (Jarrar et al., 2007); terhadap aspek-aspek pelaporan keuangan pada organisasi bisnis di Kuwait (Naser et al., 2003); terhadap implementasi US dan UK GAAP (Reinstein dan Weirich, 2002); atau terhadap integrasi dan pengendalian pada sistem akuntansi manajemen di Jerman (Weißenberger et al., 2012). Beberapa penelitian terdahulu ini memberikan hasil yang tak jauh berbeda, yaitu diperolehnya bukti adanya perbedaan persepsi di antara kedua belah pihak berkepentingan tersebut.

Penelitian yang dilakukan oleh Jarrar et al. (2007), misalnya, menemukan bahwa penyusun dan pengguna laporan keuangan memberikan persepsi berbeda terhadap hubungan pemengaruhan antara variabel kesuksesan pengimplementasian sistem Pembebanan Biaya Berdasarkan Aktivitas (Activity Based Costing (ABC)) dan beberapa variabel independen yang diajukan, berupa dukungan dan keterlibatan manajemen puncak, sinkronisasi sistem $A B C$ dengan strategi kompetitif organisasi, dan budaya serta sumberdaya keorganisasian. Pada penelitian berbeda, Ousama et al. (2011) menemukan bahwa terdapat perbedaan persepsi antara penyusun dan pengguna laporan keuangan terkait kebermanfaatan informasi terkait Modal Intelektual (Intellectual Capital) yang tersaji dalam laporan keuangan organisasi. Berdasarkan teori dan hasil-hasil penelitian terdahulu, dapat kemudian dirumuskan hipotesis tunggal dalam penelitian ini sebagai berikut:

$H_{1}$ : terdapat perbedaan persepsi antara kelompok penyusun dan pengguna laporan keuangan organisasi PMI terkait penerapan PSAK 45

\section{METODE PENELITIAN}

Penelitian ini menggunakan pendekatan penelitian kuantitatif dengan teknik pengumpulan data survei melalui penyebaran kuesioner kepada responden. Data yang dikumpulkan merupakan data primer, berupa data subjektif mengenai teknik dan konsep pelaporan keuangan yang digunakan pada PMI Provinsi dan PMI Kabupaten/Kota di wilayah Provinsi Bali serta pernyataan sikap, pemikiran, pandangan, dan pendapat berkaitan dengan penerapan PSAK 45 pada organisasi tersebut. Selain itu, digunakan juga data dalam bentuk informasi demografi responden, seperti umur, jenis kelamin, jabatan dalam organisasi, tingkat pendidikan, dan sebagainya.

\section{PENGUMPULAN DATA}

Data dikumpulkan melalui penyebaran kuesioner kepada 30 staf bagian keuangan pada 10 unit organisasi Palang Merah Indonesia (PMI) seProvinsi Bali (kelompok penyusun laporan keuangan) dan 30 pegawai pemerintahan pada Dinas Kesehatan, Dinas Sosial dan Biro Kesejahteraan Rakyat Provinsi Bali (kelompok pengguna laporan keuangan). Pemilihan sampel pada kelompok pengguna didasarkan pada pertimbangan bahwa masing-masing dari ketiga 
organisasi pemerintahan tersebut secara kelembagaan memiliki kepentingan yang signifikan atas informasi kinerja yang disajikan dalam laporan keuangan PMI. Biro Kesejahteraan Rakyat merupakan unsur staf Pemerintah Provinsi Bali sebagai donatur utama PMI yang berkepentingan atas pelaporan keuangan organisasi terkait pengelolaan sumber dana yang diberikan. Dinas Kesehatan memiliki kepentingan atas pelaporan keuangan PMI berkaitan dengan penyelenggaraan program-program di bidang kesehatan. Sementara itu, Dinas Sosial memiliki kepentingan atas pelaporan keuangan PMI berkaitan dengan penyelenggaraan program-program di bidang kemanusiaan dan kesejahteraan sosial masyarakat.

\section{PENGUKURAN VARIABEL}

Variabel 'Kepatuhan Penerapan' didefinisikan sebagai ukuran besarnya intensitas kesesuaian tata cara dan sistematika pelaporan keuangan yang mengacu pada standar atau spesifikasi tertentu, dalam hal ini yaitu PSAK 45. Responden (kelompok penyusun) diberikan 30 item pertanyaan terkait praktek pencatatan Akuntansi organisasi yang mengacu pada PSAK 45 sehubungan dengan Prinsip Pengakuan (19 item pertanyaan), Prinsip Pengungkapan (empat item pertanyaan), dan Prinsip Penyajian (7 item pertanyaan). Pengukuran variabel dilakukan dengan menggunakan skala Likert lima point dengan skor ' 1 ' bernilai 'Tidak Pernah' hingga '5' bernilai 'Selalu'.

Variabel 'Persepsi Penerapan' didefinisikan sebagai tingkat pengetahuan responden tentang PSAK 45, pandangan terhadap eksistensi dan legalitas PSAK 45, serta pendapat terkait penerapan PSAK 45 pada organisasi PMI. Responden (kelompok penyusun dan kelompok pengguna) masing-masing diminta memberikan persetujuannya terhadap 15 item pertanyaan sehubungan dengan ketiga aspek persepsi sebagaimana didefinisikan sebelumnya. Pengukuran variabel dilakukan dengan menggunakan skala Likert lima point dengan skor '1' bernilai 'Sangat Tidak Setuju' hingga '5' bernilai 'Sangat Setuju'.

\section{TEKNIK ANALISIS DATA}

Eksplorasi terhadap variabel 'Tingkat Kepatuhan' serta variabel 'Persepsi' kelompok penyusun dan pengguna laporan keuangan dilakukan dengan menggunakan teknik statistika deskriptif, yaitu melalui penentuan nilai mean (ratarata) jawaban tiap-tiap item pertanyaan. Nilai tendensi sentral ini dihitung dengan membagi nilai total skor variabel dari tiap responden dengan jumlah skor ideal untuk variabel tersebut. Skor ideal yang dimaksud adalah nilai maksimum yang dapat dicapai dalam pengisian kuesioner, yaitu apabila semua responden memilih pilihan jawaban dengan skor tertinggi untuk seluruh pertanyaan dalam kuesioner.

Nilai mean yang diperoleh kemudian dibandingkan dengan kriteria yang telah ditetapkan sebelumnya untuk menentukan ukuran kualitatif tingkat kepatuhan penerapan PSAK 45 serta persepsi kelompok penyusun dan pengguna laporan keuangan organisasi PMI. Kriteria-kriteria yang dimaksud terklasifikasi menjadi beberapa kategori sebagaimana disajikan pada Tabel 1 dan Tabel 2 . Kriteria ini ditentukan melalui perhitungan matematis terhadap rentang data dan panjang kelas interval rata-rata masing-masing variabel sehingga mengahsilkan Interval Tingkat Kepatuhan (ITK) dan Interval Persepsi (IP).

Selanjutnya, dengan bantuan program SPSS for Windows versi 11.5, alat analisis Independent Sample ttest (untuk data yang terdistribusi normal) dan uji Mann-Whitney test (untuk data yang tidak terdistribusi normal) digunakan dalam rangka menguji hipotesis yang diajukan dalam penelitian 
ini. Hipotesis dinyatakan terdukung apabila diperoleh nilai signifikansi sebesar $<0,5$ untuk masing-masing alat uji beda statistik.

\section{TABEL 1. KETEGORI KEPATUHAN PENERAPAN}

\begin{tabular}{ll}
\hline Kriteria Variabel Kepatuhan & Interval Tingkat Kepatuhan (ITK) \\
\hline Sangat Tidak Patuh & $20 \%-36 \%$ \\
Tidak Patuh & $>36 \%-52 \%$ \\
Kurang Patuh & $>52 \%-68 \%$ \\
Patuh & $>68 \%-84 \%$ \\
Sangat Patuh & $>84 \%-100 \%$
\end{tabular}

TABEL 2. KATEGORI PERSEPSI PENERAPAN

\begin{tabular}{ll}
\hline Kriteria Variabel Persepsi & Interval Persepsi (IP) \\
\hline Sangat Tidak Setuju & $20 \%-36 \%$ \\
Tidak Setuju & $>36 \%-52 \%$ \\
Kurang Setuju & $>52 \%-68 \%$ \\
Setuju & $>68 \%-84 \%$ \\
Sangat Setuju & $>84 \%-100 \%$
\end{tabular}

\section{HASIL DAN PEMBAHASAN}

Sejumlah total 10 kuesioner terkait variabel 'Kepatuhan Penerapan' (tipe I) dan 60 kuesioner terkait variabel 'Persepsi Penerapan' (tipe II) telah disebarkan. Kuesioner tipe I ditujukkan kepada satu orang bagian keuangan pada masing-masing kantor cabang organisasi yang tersebar di sembilan kabupaten/kota serta pada satu kantor pusat yang berkedudukan di ibukota provinsi. Kuesioner tipe II ditujukan kepada 30 responden pihak penyusun dan 30 responden pihak pengguna laporan keuangan. Dari jumlah tersebut, keseluruhan kuesioner berhasil kembali dan layak untuk digunakan (response rate 100\%). Tingkat pengembalian yang tinggi ini diperoleh karena kuesioner diantar dan diambil dari responden secara langsung.

Secara demografis, untuk kelompok penyusun laporan keuangan, sejumlah 56,67\% responden berjenis kelamin laki-laki, sebanyak $40 \%$ berlatar belakang pendidikan terakhir Sekolah Menengah Atas (SMA)/sederajat, 50\% responden telah bekerja selama lebih dari 50 tahun serta sebagian besar tidak memiliki pengetahuan berbasis akuntansi $(56,67 \%)$ dan tidak pernah mengikuti pelatihan terkait pengelolaan keuangan $(66,67 \%)$. Sementara itu, 53,33\% responden pada kelompok pengguna laporan keuangan berjenis kelamin perempuan, $73,33 \%$ berlatar belakang pendidikan terakhir sarjana strata1 (S1), 53,33\% telah bekerja lebih dari 50 tahun, 66,67\% memiliki pengetahuan berbasis akuntansi dan hanya 20\% yang pernah mengikuti pelatihan terkait pengelolaan keuangan.

\section{TINGKAT KEPATUHAN PENERAPAN PSAK 45}

Dalam rangka mengeksplorasi tingkat kepatuhan penerapan PSAK 45 oleh organisasi PMI se-Provinsi Bali, evaluasi dilakukan pada masing-masing kantor cabang organisasi. Sebagaimana ditampilkan pada Tabel 3, hasil penelitian menunjukkan bahwa (a) organisasi PMI Provinsi Bali berada dalam kategori 'Tidak Patuh' dengan interval tingkat kepatuhan (ITK) sebesar 0,46; (b) PMI Kabupaten Buleleng terkategori 'Tidak Patuh' (ITK=0,52); (c) PMI Kabupaten Bangli terkategori 'Sangat Tidak Patuh' (ITK=0,34); (d) PMI Kabupaten Tabanan terkategori 'Sangat Tidak Patuh; (ITK=0,253); (e) PMI Kabupaten Klungkung terkategori 'Tidak Patuh' (ITK=0,52); (f) PMI Kabupaten Karangasem terkategori 'Tidak Patuh' (ITK=0,0453); (g) PMI Kabupaten Gianyar terkategori 'Patuh' (ITK=0,713); (h) PMI Kabupaten Jembrana terkategori 'Tidak Patuh' (ITK=0,380); (i) PMI Kota Denpasar terkategori 'Patuh' (ITK=0,753); dan (j) PMI Kabupaten Badung terkategori 'Patuh' (ITK=0,687).

Analisis lebih mendalam terhadap jawaban responden untuk indikator prinsip Pengakuan, menunjukkan bahwa hanya dua unit organisasi yang secara konsisten melakukan pencatatan atas sebagian besar akun-akun laporan keuangan sebagaimana dipersyaratkan dalam PSAK 45, yaitu 
PMI Kota Denpasar (63,16\%) dan PMI Kabupaten Badung (63,25\%). Sementara itu, delapan unit organisasi lainnya berada pada rentangan nilai pencatatan sebesar $15-30 \%$.

Sehubungan dengan prinsip Pengung-kapan, empat unit organisasi yaitu PMI Kabupaten Karangasem, PMI Kabupaten Gianyar, PMI Kota Denpasar dan PMI Kabupaten Badung terbukti telah melakukan pengungkapan informasiinformasi tambahan dengan sangat memadai (intensitas pengungkapan 50-100\% per periode), misalnya atas rincian sumber daya dan kewajiban yang tidak tercantum pada bagian utama laporan keuangan, dasar kebijakan Akuntansi yang diterapkan serta pembatasan penggunaan aktiva organisasi.

Terakhir, dalam hal prinsip Penyajian, terdapat tiga unit organisasi yang secara sistematis dan memadai telah menyajikan unsur-unsur pada laporan keuangan, yaitu PMI Kabupaten Klungkung (42,86\%), PMI Kabupaten Gianyar (57,14\%) dan PMI Kabupaten Badung (57,14\%). Penyajian yang dimaksud misalnya berupa penyajian akun aktiva dan kewajiban dengan pengumpulan atas unsur-unsur tersebut ke dalam kelompok yang memiliki karakteristik serupa dan relatif homogen, menyajikan jumlah pendapatan dan beban secara bruto serta menyajikan pendapatan, sumbangan dan kerugian sebagai penambah aktiva bersih tidak terikat.

\section{PERSEPSI PENERAPAN PSAK 45}

Hasil penelitian terkait variabel Persepsi Penerapan (Tabel 4 dan Tabel 5) menunjukkan bahwa kelompok penyusun laporan keuangan memiliki persepsi 'Kurang Setuju' terhadap penerapan PSAK 45 dengan nilai interval persepsi (IP) sebesar 0,657; sedangkan persepsi yang dimiliki kelompok pengguna laporan keuangan berada pada kategori 'Setuju' dengan IP sebesar 0,754.
Lebih jauh, pada kelompok penyusun laporan keuangan, ditemukan bahwa indikator 'pengetahuan tentang PSAK 45', 'pandangan terhadap eksistensi dan legalitas PSAK 45', dan 'pendapat terkait penerapan PSAK 45', masingmasing terkategori 'Kurang Setuju' (IP=0,524), 'Kurang Setuju' (IP=0,673), dan 'Setuju' (IP=0,746). Sementara itu, pada kelompok pengguna laporan keuangan, indikator 'pengetahuan tentang PSAk 45' berada dalam kategori 'Kurang Setuju' (IP=0,637), indikator 'pandangan terhadap eksistensi dan legalitas PSAK 45' pada kategori 'Setuju' $(\mathrm{IP}=0,764)$ dan indikator 'pendapat terkait penerapan PSAK 45' pada kategori 'Setuju' $(\mathrm{IP}=0,833)$.

TABEL 3. HASIL PENILAIAN VARIABEL KEPATUHAN PENERAPAN PSAK 45

\begin{tabular}{lllll}
\hline Unit Organisasi PMI & Skor Total & Skor Ideal & $\begin{array}{l}\text { Interval } \\
\text { Kepatuhan }\end{array}$ & Kategori Kepatuhan \\
\hline PMI Provinsi Bali & 69 & 150 & 0,460 & Tidak Patuh \\
PMI Kabupaten Buleleng & 78 & 150 & 0,520 & Tidak Patuh \\
PMI Kabupaten Bangli & 63 & 150 & 0,340 & Sangat Tidak Patuh \\
PMI Kabupaten Tabanan & 38 & 150 & 0,253 & Sangat Tidak Patuh \\
PMI Kabupaten Klungkung & 78 & 150 & 0,520 & Tidak Patuh \\
PMI Kabupaten Karangasem & 68 & 150 & 0,453 & Tidak Patuh \\
PMI Kabupaten Gianyar & 107 & 150 & 0,713 & Patuh \\
PMI Kabupaten Jembrana & 57 & 150 & 0,380 & Tidak Patuh \\
PMI Kota Denpasar & 113 & 150 & 0,753 & Patuh \\
PMI Kabupaten Badung & 103 & 150 & 0,687 & Patuh \\
\hline
\end{tabular}

Eksplorasi lebih jauh mengungkap bahwa sejumlah 43,33\% responden kelompok penyusun dan 53,33\% responden kelompok pengguna telah mengetahui adanya standar baku pelaporan keuangan bagi organisasi nirlaba. Di sisi lain, sejumlah 53,33\% responden kelompok penyusun dan $73,33 \%$ responden kelompok pengguna menyatakan persetujuannya terhadap legalitas PSAK 45. Terakhir, sejumlah 70\% responden kelompok penyusun dan 93,33\% responden kelompok pengguna berpendapat bahwa penerapan PSAK 45 pada organisasi PMI akan dapat meningkatkan kualitas layanan, aspek akuntabilitas dan transparansi pengelolaan keuangan organisasi. 


\section{PENGUJIAN INSTRUMEN PENELITIAN}

Pengujian terhadap instrumen penelitian dilakukan dalam rangka memperoleh kepastian kualitas alat pengumpulan data yang digunakan terkait aspek validitas dan reliabilitas. Secara umum, keseluruhan item pertanyaan pada variabel Persepsi Penerapan telah memenuhi kriteria pengujian sehingga dapat dikatakan valid dan reliable. Sebagaimana disajikan pada Tabel 6, nilai koefisien korelasi untuk ketiga indikator pada masing-masing kelompok responden berada pada rentang 0,4-0,8. Nilai ini terkategori valid karena berada di atas batas minimal 0,3 (Sugiyono, 2010). Sementara itu, nilai cronbach's alpha berada pada kisaran angka 0,6-0,9 dan terkategori reliabel dengan berpedoman pada standar reliabilitas 0,6 (Ghozali, 2009).

\begin{tabular}{llllll}
$\begin{array}{l}\text { TABEL 4. HASIL PENILAIAN VARIABEL PERSEPSI PENERAPAN PSAK } 45 \\
\text { KELOMPOK PENYUSUN }\end{array}$ \\
\hline Variabel/Indikator & $\begin{array}{c}\text { Skor } \\
\text { Total }\end{array}$ & $\begin{array}{l}\text { Skor } \\
\text { Ideal }\end{array}$ & $\begin{array}{l}\text { Interval } \\
\text { Persepsi }\end{array}$ & Kategori Persepsi \\
\hline Variabel Persepsi Penerapan & 858 & 2250 & 0,657 & Kurang Setuju \\
Indikator Pengetahuan tentang PSAK 45 & 393 & 750 & 0,524 & Kurang Setuju \\
Indikator Pandangan Legalitas PSAK 45 & 303 & 450 & 0,673 & Kurang Setuju \\
Indikator Pendapat Penerapan PSAK 45 & 783 & 1050 & 0,746 & Setuju \\
\hline
\end{tabular}

\section{TABEL 5. HASIL PENILAIAN VARIABEL PERSEPSI PENERAPAN PSAK 45} KELOMPOK PENGGUNA

\begin{tabular}{lcccc}
\hline Variabel/Indikator & Skor Total & $\begin{array}{l}\text { Skor } \\
\text { Ideal }\end{array}$ & $\begin{array}{l}\text { Interval } \\
\text { Persepsi }\end{array}$ & Kategori Persepsi \\
\hline $\begin{array}{l}\text { Variabel Persepsi Penerapan } \\
\text { Indikator Pengetahuan tentang }\end{array}$ & 1697 & 2250 & 0,754 & Setuju \\
$\begin{array}{l}\text { PSAK 45 } \\
\text { Indikator Pandangan Legalitas }\end{array}$ & 344 & 750 & 0,637 & Kurang Setuju \\
$\begin{array}{l}\text { PSAK 45 } \\
\text { Indikator Pendapat Penerapan }\end{array}$ & 875 & 1050 & 0,833 & Setuju \\
PSAK 45 & & & & \\
\hline
\end{tabular}

Pengujian selanjutnya dilakukan sehubungan dengan aspek normalitas data dalam rangka menentukan alat analisis yang tepat untuk pengujian hipotesis penelitian. Berdasarkan Tabel 7 diketahui bahwa pada kelompok penyusun laporan keuangan, data untuk indikator 'Pengetahuan Tentang PSAK 45' dan 'Pandangan Terkait Legalitas PSAK 45' memiliki nilai signifikansi lebih dari 0,05 (masing-masing 0,449 dan 0,184) sehingga dapat dinyatakan bahwa data yang diperoleh terkait indikator-indikator tersebut terdistribusi secara normal. Sementara itu, untuk indikator 'Pendapat Mengenai Penerapan PSAK 45 di PMI Bali' memiliki nilai signifikansi kurang dari 0,05 $(0,041)$ sehingga data yang diperoleh dapat dinyatakan tidak terdistribusi secara normal.

Tabel 7 juga menyajikan hasil pengujian normalitas data terkait indikator-indikator pada variabel Persepsi Penerapan PSAK 45 untuk kelompok pengguna laporan keuangan. Data untuk keseluruhan indikator memiliki nilai signifikansi lebih dari 0,05 (masing-masing 0,297 untuk indikator 'Pengetahuan Tentang PSAK 45', 0,096 untuk indikator 'Pandangan Terkait Legalitas PSAK 45', dan 0,085 untuk indikator 'Pendapat Mengenai Penerapan PSAK 45 di PMI Bali'). Dengan mempertimbangkan hasil ini, pengujian hipotesis terkait indikator 'Pengetahuan Tentang PSAK 45' dan 'Pandangan Terkait Legalitas PSAK 45' dilakukan menggunakan alat analisis Independent t-test, sementara untuk indikator 'Pendapat Mengenai Penerapan PSAK 45 di PMI Bali’ menggunakan alat uji Mann-Whitney test.

\section{PENGUJIAN HIPOTESIS}

Pengujian hipotesis penelitian dilakukan dengan menggunakan uji Independent Sample t-test untuk variabel 'Persepsi Penerapan PSAK 45', indikator 'Penge-tahuan tentang PSAK 45' dan indikator 'Pandangan terkait Legalitas PSAK 45' serta uji statistik Mann-Whitney test untuk indikator 'Pendapat mengenai Penerapan PSAK 45 di Palang Merah Indonesia se-Provinsi Bali'. 
TABEL 6. HASIL UJI VALIDITAS DAN RELIABILITAS INSTRUMEN PENELITIAN

\begin{tabular}{lllll}
\hline \multirow{3}{*}{ Indikator } & \multicolumn{2}{l}{ Kelompok Penyusun } & \multicolumn{2}{l}{ Kelompok Pengguna } \\
\cline { 2 - 5 } & $\begin{array}{l}\text { Koefisien } \\
\text { Korelasi }\end{array}$ & $\begin{array}{l}\text { Cronbach's } \\
\text { Alpha }\end{array}$ & $\begin{array}{l}\text { Koefisien } \\
\text { Korelasi }\end{array}$ & $\begin{array}{l}\text { Cronbach's } \\
\text { Alpha }\end{array}$ \\
\hline $\begin{array}{l}\text { Pengetahuan Tentang } \\
\text { PSAK 45 }\end{array}$ & 0,8023 & 0,9217 & 0,5106 & 0,7375 \\
$\begin{array}{l}\text { Pandangan Terkait } \\
\text { Legalitas PSAK 45 }\end{array}$ & 0,5821 & 0,7471 & 0.4809 & 0,6395 \\
$\begin{array}{l}\text { Pendapat Mengenai } \\
\text { Penerapan PSAK 45 }\end{array}$ & 0,7604 & 0,9214 & 0,6119 & 0,8379 \\
\hline
\end{tabular}

TABEL 7. HASIL UJI NORMALITAS DATA

\begin{tabular}{lll}
\hline \multirow{2}{*}{ Indikator } & \multicolumn{2}{l}{ Nilai Signifikansi } \\
\cline { 2 - 3 } & $\begin{array}{l}\text { Kelompok } \\
\text { Penyusun }\end{array}$ & $\begin{array}{l}\text { Kelompok } \\
\text { Pengguna }\end{array}$ \\
\hline $\begin{array}{l}\text { Pengetahuan Tentang } \\
\text { PSAK 45 }\end{array}$ & 0,449 & 0,297 \\
$\begin{array}{l}\text { Pandangan Terkait } \\
\text { Legalitas PSAK 45 }\end{array}$ & 0,184 & 0,096 \\
$\begin{array}{l}\text { Pendapat Mengenai } \\
\text { Penerapan PSAK 45 }\end{array}$ & 0,041 & 0,085 \\
\hline
\end{tabular}

Hasil pengujian hipotesis terhadap variabel Persepsi Penerapan PSAK 45 (Tabel 8 panel A) menunjukkan bahwa terdapat perbedaan yang signifikan $(\dot{a}<0,01)$ antara kelompok penyusun dan pengguna laporan keuangan. Mean jawaban yang lebih besar pada kelompok pengguna $(3,7711)$ dibandingkan pada kelompok penyusun $(3,2867)$ menunjukkan bahwa kelompok pengguna mempersepsikan secara lebih positif (baik/setuju) penerapan PSAK 45 pada organisasi PMI seProvinsi Bali.

Terkait indikator pengetahuan tentang PSAK 45 (Tabel 8 panel B), ditemukan adanya perbedaan yang signifikan $(\dot{a}<0,05)$ antara jawaban responden kelompok penyusun (mean 2,6200) dan responden kelompok pengguna (mean 3,1867).

Temuan ini mengisyaratkan bahwa kelompok pengguna memiliki pengetahuan yang lebih baik terhadap eksistensi PSAK 45 sebagai standar pelaporan keuangan organisasi nirlaba. Sementara itu, perbedaan yang signifikan juga dapat diamati pada jawaban kedua kelompok responden terkait indikator pandangan legalitas PSAK 45 (Tabel 8 panel C) dan pendapat mengenai penerapan PSAK 45 (Tabel 8 panel D). Untuk masing-masing indikator tersebut, berturut-turut, diperoleh mean jawaban sebesar 3,3667 (penyusun) dan 3,8222 (pengguna) dengan nilai signifikansi á<0,05 serta sum of ranks mean jawaban sebesar 656,00 (penyusun) dan 117,00 (pengguna) dengan nilai signifikansi $a<<0,01$. Dengan demikian, dapat dinyatakan bahwa hipotesis yang diajukan dalam penelitian ini terdukung secara statistik.

TABEL 8. HASIL PENGUJIAN HIPOTESIS

\begin{tabular}{|c|c|c|c|}
\hline $\begin{array}{l}\text { A. Variabel Persepsi } \\
\text { Penerapan PSAK 45ํ) }\end{array}$ & Mean & SD & Sig. \\
\hline Kelompok Penyusun & 3,2867 & 0,61704 & $0,000^{* *}$ \\
\hline Kelompok Pengguna & 3,7711 & 0,32315 & \\
\hline $\begin{array}{l}\text { B. Indikator Pengetahuan } \\
\text { Tentang PSAK 450) }\end{array}$ & Mean & SD & Sig. \\
\hline Kelompok Penyusun & 2,6200 & 1,03770 & $0,021^{*}$ \\
\hline Kelompok Pengguna & 3,1867 & 0,80161 & \\
\hline $\begin{array}{l}\text { C. Indikator Pandangan } \\
\text { Terkait Legalitas PSAK 450) }\end{array}$ & Mean & SD & Sig. \\
\hline Kelompok Penyusun & 3,3667 & 0,75481 & $0,010^{*}$ \\
\hline Kelompok Pengguna & 3,8222 & 0,55869 & \\
\hline $\begin{array}{l}\text { D. Indikator Pendapat } \\
\text { Mengenai Penerapan } \\
\text { PSAK 45) }\end{array}$ & Mean Rank & $\begin{array}{l}\text { Sum of } \\
\text { Ranks }\end{array}$ & Sig. \\
\hline Kelompok Penyusun & 21,87 & 656,00 & $0,000^{* *}$ \\
\hline Kelompok Pengguna & 39,13 & 117,00 & \\
\hline
\end{tabular}

\section{SIMPULAN}

Penelitian ini bertujuan untuk mengevaluasi tingkat kepatuhan penerapan organisasi terhadap PSAK 45 sebagai standar pelaporan keuangan nasional bagi organisasi nirlaba di Indonesia, menginvestigasi persepsi kelompok penyusun dan pengguna laporan keuangan terkait standar tersebut; dan menentukan apakah terdapat perbedaan persepsi antara kedua kelompok 
tersebut. Secara umum, hasil penelitian menemukan bukti bahwa tingkat kepatuhan penerapan organisasi PMI se-Provinsi Bali terhadap standar pelaporan keuangan nasional tergolong rendah. Sebagian besar unit organisasi yang menjadi subjek penelitian masih berada pada kategori ‘Tidak Patuh’ berdasarkan kriteria penilaian yang telah ditetapkan sebelumnya. Hanya tiga dari 10 unit organisasi yang telah dengan memadai menerapkan PSAK 45 sebagai pedoman dalam penyusunan laporan keuangan organisasi, yaitu PMI Kabupaten Gianyar, PMI Kota Denpasar dan PMI Kabupaten Badung.

Hal ini dapat disebabkan karena masih diterapkannya Standar Operasional Prosedur (SOP) keuangan yang ditetapkan oleh PMI Pusat dan berlaku untuk seluruh PMI Provinsi dan PMI Kabupaten/Kota di Indonesia. Sebagai alternatif solusi, Ikatan Akuntan Indonesia sebagai badan pengembang standar pelaporan keuangan di Indonesia perlu mengadakan sosialisasi dan edukasi yang lebih intensif berkaitan dengan penerapan PSAK 45 sekaligus mengajak PMI untuk bersamasama mencari pemecahan atas masalah dualisme kewajiban penerapan aturan pelaporan keuangan tersebut.

Temuan lain yang juga perlu mendapat perhatian adalah fakta empiris bahwa pihak penyusun laporan keuangan organisasi memiliki persepsi yang lebih rendah (kurang setuju) dibandingkan kelompok pengguna laporan keuangan dalam hal penerapan PSAK 45 pada organisasi PMI. Menariknya, perbedaan persepsi antara pihak penyusun dan pengguna laporan keuangan ini juga terbukti signifikan secara statistik. Hal ini kemudian dapat menjadi bukti yang mengkonfirmasi temuan Rahman (2000) terkait sikap-sikap resistensi yang dimiliki penyusun laporan keuangan terhadap usaha-usaha untuk meningkatkan akuntabilitas dan transparansi pengelolaan keuangan.

Perbedaan ini tentunya perlu disikapi secara bijak mengingat peran sentral laporan keuangan sebagai media komunikasi di antara kedua belah pihak. Hal ini menjadi penting karena baik kelompok penyusun maupun pengguna laporan keuangan seharusnya memiliki persamaan persepsi berkaitan dengan standar pelaporan keuangan yang digunakan oleh organisasi sehingga informasi yang terkandung dalam laporan keuangan dapat samasama dipahami.

Penelitian ini, tak bisa dipungkiri, mengandung beberapa keterbatasan. Pertama, penggunaan kuesioner sebagai alat pengumpulan data utama sangat rentan terhadap resiko bawaan berupa biasbias respon, misalnya bias motif konsistensi, bias keinginan sosial, dan lainnya. Kedua, pemilihan PMI sebagai subjek penelitian sebagai representasi organisasi nirlaba tentunya tidak dapat meng \generalisasi karakteristik jenis organisasi tersebut secara keseluruhan. Hasil berbeda kemungkinan dapat muncul pada bentuk organisasi nirlaba dengan karakter operasional berbeda. Penelitian berikutnya dapat menerapkan metodemetode khusus guna meminimalisasi bias-bias kuesioner yang dapat muncul. Pengembangan penelitian selanjutnya dapat dilakukan dengan melakukan pengujian hubungan antara persepsi penyusun dan perilaku kepatuhan penerapan suatu standar pelaporan keuangan tertentu.

\section{DAFTAR PUSTAKA}

Barth, M. E., W. R. Landsman, DAN A. H. Lang. 2008. International Accounting Standards and Accounting Quality. Journal of Accounting Research, 46 (3), 467-498.

Carcello, J. V., R. H. Hermanson, dan N. T. McGrath. 1992. Audit Quality Attributes: The Perceptions of Audit Partners, Preparers, and Financial Statement Users. Auditing: A Journal of Practice \& Theory, 1 (1), 1-15.

Dang-Duc, S. 2011. Compliance with Accounting Standards by SMEs in Transitional Economies: Evidence from Vietnam. Journal of Applied Accounting Research, 12 (2), 96-107.

Ghozali, Imam. 2009. Aplikasi Analisis Multivariate dengan Program 
SPSS (Cetakan ke IV). Semarang: Badan Penerbit UNDIP

Holthausen, R.W. 2009. Accounting Standards, Financial Reporting

Outcomes, and Enforcement. Journal of Accounting Research, 47

(2), 447-458.

Hope, O. K. 2003. Disclosure Practices, Enforcement of Accounting

Standards, and Analysts' Forecast Accuracy: An International

Study. Journal of Accounting Research, 41 (2), 235-272.

Hossain, M.A. dan M. Nurunnabi. 2011. Enforcement and Compliance of Mandatory Accounting Standards in Emerging Economies: The Case od Pakistan. International Journal Managerial and Financial Accounting, 3 (2), 200-218.

Ikatan Akuntan Indonesia. 2010. DSAK-IAI Kembali Meluncurkan Standar Akuntansi Baru dan Mencabut Standar Akuntansi Koperasi dan Ekuitas. [Online] Tersedia di: http://www.iaiglobal.or.id/v02/ berita/detail. php?catid=\&id=184 [Diakses 9 Agustus 2011]

Jarrar, N.S., M. Smith. Dan C. Dolley. 2007. Perceptions of preparers and users to accounting change: a case study in an Australian university. Managerial Auditing Journal, 22 (1), 80-94.

Kreander, N., V. Beattie dan K. McPhail. 2009. Putting our money where their mouth is: Alignment of charitable aims with charity investments - Tension in policy and practice. The British Accounting Review, 41, 154-168

Levitt, A. 1998. The Importance of High Quality Accounting Standards. Accounting Horizons, 12 (1), 79-82.

Ousama, A. A., A. H. Fatima dan A. R. H. Majdi. 2011. Usefulness of intellectual capital information: preparers' and users' views. Journal of Intellectual Capital, 12 (3), 430-445.

Palang Merah Indonesia. 2010. Standard Operational Procedure (SOP) Keuangan Palang Merah Indonesia. Materi Pelatihan. Jakarta, Indonesia: Palang Merah Indonesia Pusat.

Palang Merah Indonesia. 2011. Donatur PMI. [Online] Tersedia di: http:/ /www.pmi.or.id/index.php/kapasitas/donasi/donatur-pmi.html [Diakses 14 Juli 2011].

Rahman, M. Z. 2000. Accounting Standards in The East Asia Region. In Second Asian Roundtable on Corporate Governance "The Role of Disclosure in Strengthening Corporate Governance and Accountability". Hong Kong, 2000. OECD and World Bank.

Reinstein, A. Dan R. Weirich. 2002. US and UK GAAP: Important Differences for Financial Statement Preparers and Users. Managerial Finance, 28 (1), 59-72.

Sugiyono. 2007. Metode Penelitian Bisnis (Cetakan Ke-15). Bandung: Alfabeta

Weißenberger, B.E., H. Angelkort dan G. Holthoff. 2012. MAS Integration and Controllership Effectiveness: Evidence of a Preparer-User Perception Gap. German Academic Association for Business Research, 5 (2), 134-153.

World Bank. 2007. Pakistan Public Sector Accounting and Auditing: A Comparison to International Standards. The World Bank: South Asia Region Financial Management Unit. 